\title{
Financial Literacy and Retirement Planning in Vietnam
}

\author{
Do Thu Huong ${ }^{*}$ \\ VNU International School, Building G7, 144 Xuan Thuy, Cau Giay, Hanoi, Vietnam \\ Received 26 April 2017 \\ Revised 10 June 2017; Accepted 28 June 2017
}

\begin{abstract}
In the context of a "getting old before getting rich" population, pension schemes in Vietnam are now facing many challenges which may lead to depletion in 2034 if no effective reform takes place shortly. Though there is still no blueprint for a nationwide reform, household behavior adjustments such as better retirement preparedness and planning may create important changes. By examining the current state of financial literacy and the elderly's financial situation, the research reveals that financial literacy is of primary importance for retirement security in Vietnam.
\end{abstract}

Keywords: financial literacy, retirement planning, pension funds.

\section{Introduction}

In the coming decades, the world population will be ageing ${ }^{1}$ rapidly, and this is driven by increasing longevity and low fertility rates. Such an ageing population will pose persistent challenges. Within the world-wide ageing trend, there is a considerable heterogeneity across regions and countries. According to the most recent demographic data OECD (2015), the share of individuals aged 65 and above will increase from $8 \%$ of the total world population in 2015 to almost $18 \%$ by 2050 [1]. In the OECD countries, the share of the population older than 65 years will shift from $16 \%$ in 2015 to $27 \%$ in 2050 . This number is projected to more than triple, on average, between 2000 and 2050 throughout the Asian

\footnotetext{
Tel.: 84-904277556.

Email: huongdt@isvnu.vn

https://doi.org/10.25073/2588-1116/vnupam.4078
}

region the majority of which are still in the stages of [2].

"Getting old before getting rich" is now regarded as one of most important features of the population ageing phenomenon in most of developing Asian countries. In Vietnam, according to UNFPA (2011), the growth of the old population is rather high whereas the per capita income is only just reaching the level of a low middle-income country ${ }^{1}$ (about \$US 1,170 per capita in 2010) [3]. Vietnam will face an ageing population in the coming decades. The growth in the supply of labour is slowing down, and the old-age dependency ratio is expected to be significantly higher in the future.

\footnotetext{
1 In 2015, the United Nations classifies countries in income groups on the basis of Gross National Income index: Least developed countries, Low-income economies (GNI per capita $\$ 1,045$ or less), Lower-middle-income economies (GNI per capita $\$ 1,046$ to $\$ 4,125$ ), Uppermiddle-income economies (GNI per capita $\$ 4,126$ \$12,735), High-income economies (GNI per capita $\$ 12,736$ or more)
} 
Its pension scheme is a Pay-As-You-Go system, and the pension burden is also highly dependent on the development of the population by age and the size of the labour force.

There is growing concern that these demographic changes will remarkably impact the worldwide macroeconomic indicators and pose serious fiscal policy challenges. Furthermore, its unprecedented nature means that earlier historical episodes may not help guiding on how this demographic challenge will be conquered or on how best to manage it [4]. Recently, the economic crisis and its aftermath of sluggish economic growth have added further strains. Peterson (1999), as quoted in Bloom, Canning and Fink (2009, p.594) argues that "global ageing could trigger a crisis that engulfs the world economy [and] may even threaten democracy itself" $[4,5]$. Park (2012) points out two major challenges that population ageing poses for policy makers: ensuring high economic growth in the face of less favorable demographic conditions; and providing adequate and sustainable pensions schemes for a growing aged population [6].

Indeed, ageing directly affects the financial sustainability of PAYG pension schemes ${ }^{2}$, as a decreasing workforce has to cover pension funding for an increasing number of old people. Ultimately, not only defined-benefit but even defined-contribution (DC) schemes may not be immune to the potential lowering of the economy's output due to demographic changes. D. Bloom and Mc Kinnon (2013) cite a number of challenges facing all countries in their endeavours to provide the elderly protection including (i) the rising elder shares in the total population, (ii) lack of financial literacy ${ }^{3}$, (iii)

\footnotetext{
${ }^{2}$ According to UNFPA Vietnam (2011) pay-as-you-go (PAYG) is a method of financing where current outlays on pension benefits are paid out of current revenues from an earmarked tax, often a payroll tax. In the future, when current contributors will become pensioners, their benefits will be paid by contributions from the subsequent working generations.

${ }^{3}$ OECD defined financial literacy as a combination of awareness, knowledge, skill, attitude and behaviour
}

public budget constraints and competing government spending priorities, (iv) evolving labour markets and family structures [7].

The situation is more urgent in Vietnam as the country does not yet have well-established pension systems which are able to financially secure their growing old populations, and even the more mature pension systems in the region suffer from a wide array of structural defects that must be addressed. ILO (2010) reports that in low-income countries, less than 20 per cent of the elderly receive pension benefit, while the share of the median of this group of countries is only 7\% [8]. Giang (2010) reveals that Vietnamese pension scheme is facing many challenges: persistently low coverage ${ }^{4}$, particularly for the informal sector workers via the voluntary scheme; low compliance rate among mandated participants, especially in private sector; and unfair benefit between public and private sector and between men and women. These challenges render the pension system unable to cover people who are more vulnerable to poverty [9].

In addition, the lack of transparency in investment options and in portfolio structures may significantly influence the affordability of pension payments for the ageing population as well as future fiscal balances and economic growth. In some countries, namely China, Vietnam, Pakistan, and Taiwan (China), replacement rate ${ }^{5}$ are high relative to earnings. Early retirement ages, especially for women, exert more financial pressures.

Current pension system in Vietnam is are unlikely to sustainably face to the ageing population because of: (i) low coverage of formal pension systems; (ii) common

necessary to make sound financial decisions and ultimately achieve individual financial wellbeing.

${ }^{4}$ According to the 2015 World population ageing report by United Nations, the potential coverage reflects the percentage of persons over the statutory pensionable age that is receiving a pension.

${ }^{5}$ As defined by UNFPA Vietnam (2011), the replacement rate is the value of pension as a proportion of a worker's pre-retirement wage. 
withdrawal of savings before retirement; and (iii) pension payment unable to adjust with changes in the living cost [10].

This research provides an overview of financial literacy in general as well as current financial situation of the elderly in Vietnam and then addresses the importance of improving financial literacy and retirement preparedness in the elderly's financial security in Vietnam by analyzing the relation between financial literacy and lifetime utility.

\section{Financial situation and Retirement planning of the elderly}

Vietnamese culture developed the tradition of respect for the elderly which used to encourage informal financial supports for their care. Nonetheless, the need for formal sources for the aged population security became increasingly essential along with the economic transformation. Indeed, the changes of economic structure from agriculture-based to industrial production have significantly reduced the agrarian population. The urbanization with strong flows of immigrants from rural to urban areas have progressively eroded traditional family structure which would lead to the increase of the elderly living without care and support from families.

In the Vietnam National Ageing Survey VNAS (2011), the first-ever nationally representative survey on the elderly in Vietnam [11], only $16 \%$ of old people surveyed estimate that pension constitutes their primary source of income. Those people who are either not automatically able to benefit from pensions funds or not confident that pension could cover their expenses would need basic knowledge in compound interest, inflation and risk diversification to manage their asset. Good numeracy is also necessary for them to calculate how much to save to ensure their wellbeing when reaching retirement age.

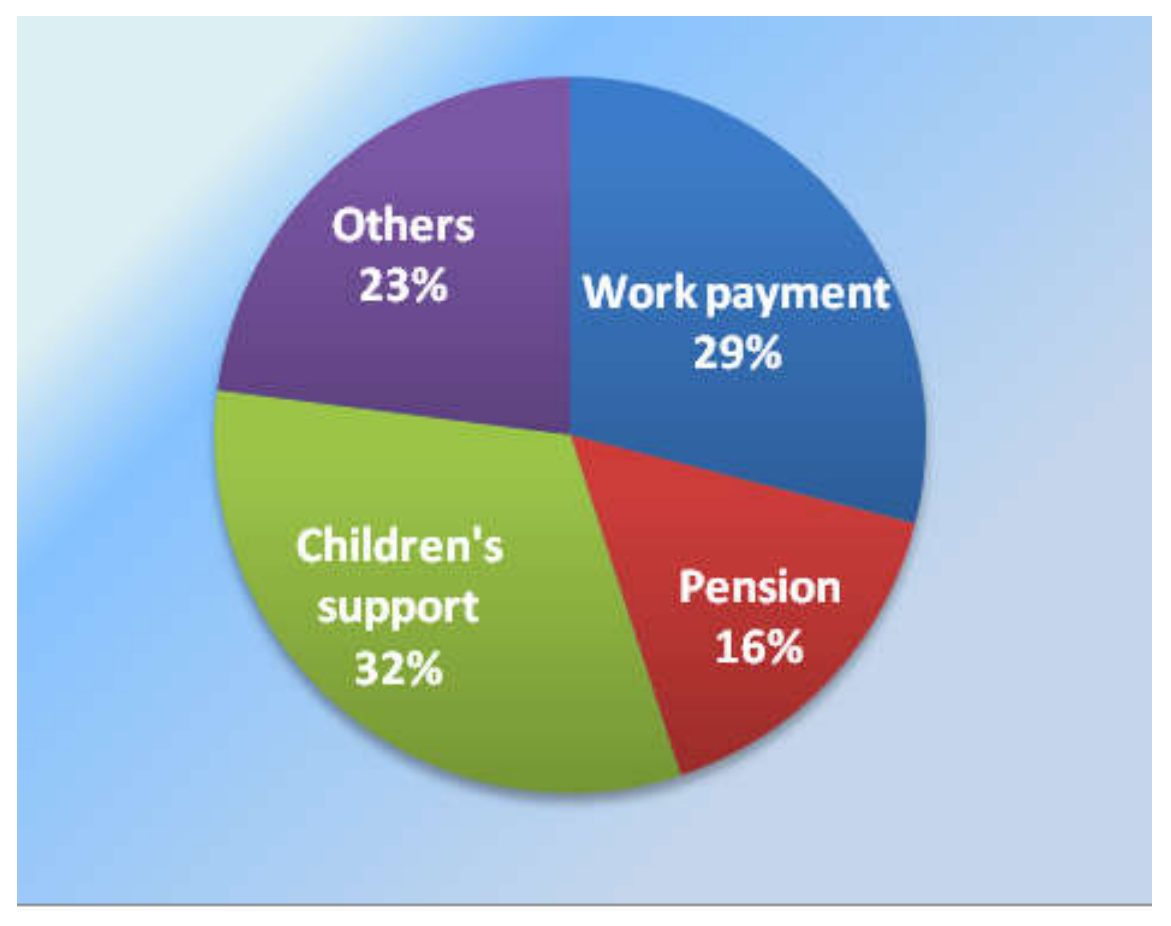

Figure 1. Self assess of the most important source of income for daily expenses.

Source: Vietnam National Ageing Survey (2011)[11] 
Financial situation of the elderly in Vietnam is not quite optimist (figure 2). According the VNAS (2011), more than one-third of the elderly self-estimate as financially sufficient or wealth, the remaining $62,4 \%$ of the surveyed people must live in a financial situation permanently or sometimes insufficient. Only $10,4 \%$ of the surveyed ones has savings [11].
The main reason of the savings is for their retirement and for emergencies such as sickness, diseases $(76,6 \%$ of the people having savings). In consequence, having a regular source of income either from work, retirement or social allowance is extremely important to the old population in Vietnam.

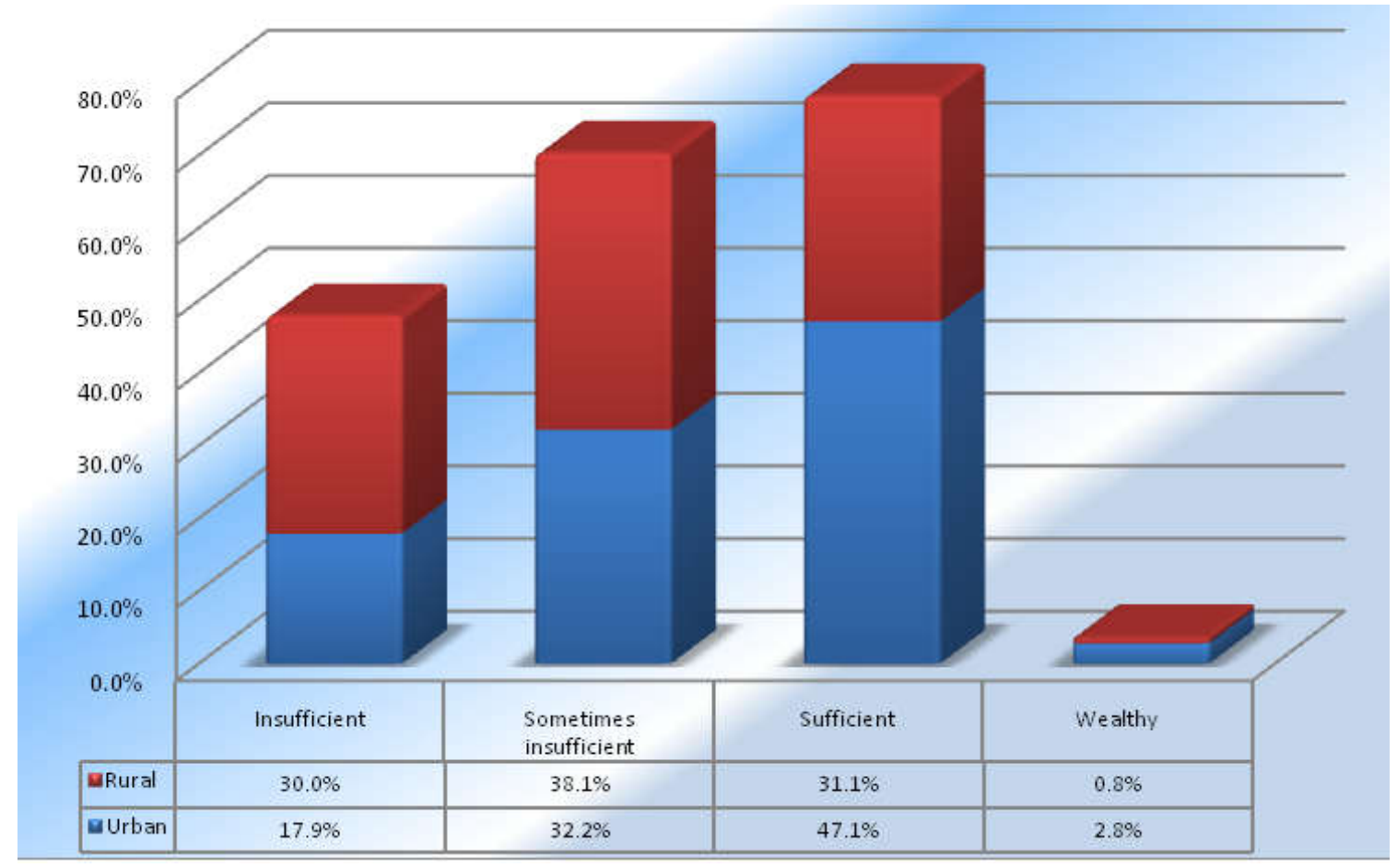

Figure 2. Self- assessment of household's financial situation.

Source: Vietnam National Ageing Survey (2011)

Dramatic socio-economic changes as a result of the Renovation (Doi moi) in 1986 activated the first reform of the pension schemes on 1995 which established a publiclymanaged Pay-As-You-Go Defined-benefit scheme (PAYG DB) with a contributory scheme and a non-contributory scheme. According to Giang (2014), the contributory scheme is mandatory for 10.9 million contributors who are civil servants and workers of State Owned Enterprises, as well as contractbased private sector workers [12]. There are only 0,6 million voluntary contributors participate to pension schemes. The financial sustainability of the pension schemes of Vietnam is problematic, not only due to such low coverage but also because a Definedbenefit scheme is not able to insulate the system from demographic shocks which is happening in Vietnam. Indeed, the country is shifting from a young population in 1979 to a dividend demographic in 2009 and an aged and very aged population in respectively 2034 and 2050 as shown in figure 3 . 


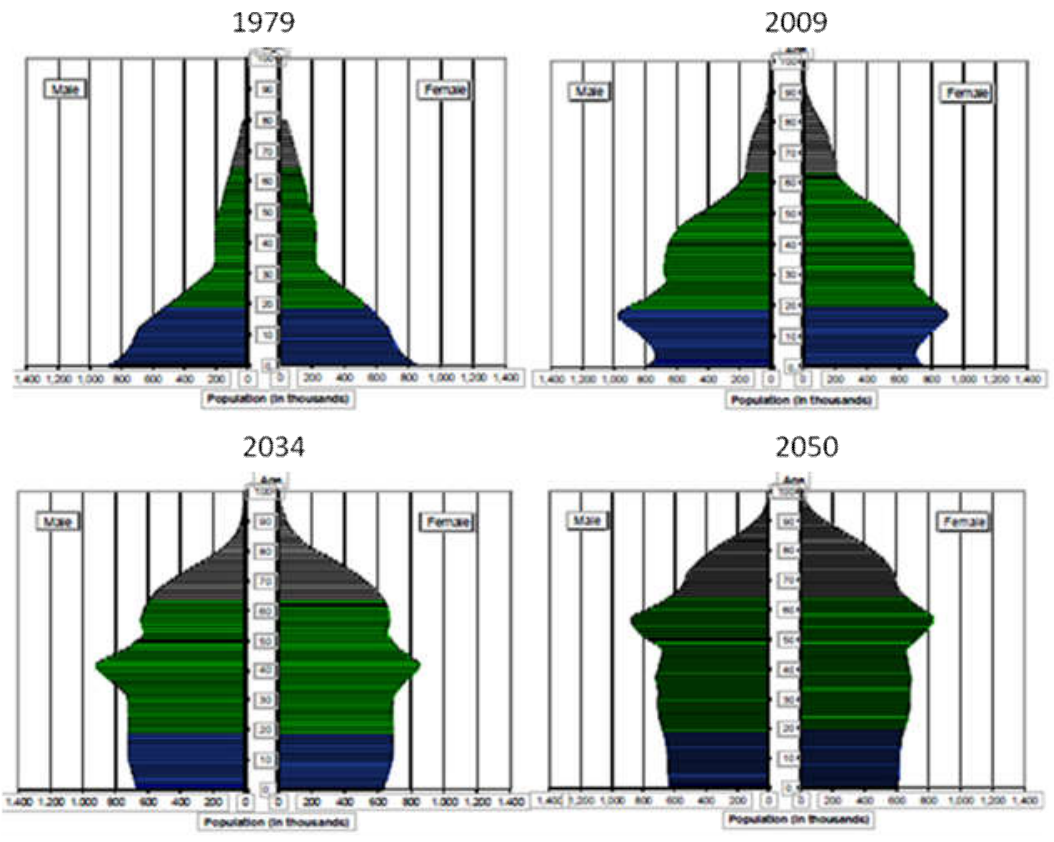

Figure 3. Sketch on Demographic transitions in Vietnam.

Source: Giang (2014), based on United Nations' statistics and projections in 2010 [12]

Giang (2014) calculates that 28-year contribution of a representative worker will be paid only for 10 years, yet the expected receiving period is 19,5 years and the
Vietnamese pension schemes faces serious risk of depletion without any reforms in 2034 (figure 4) [12].

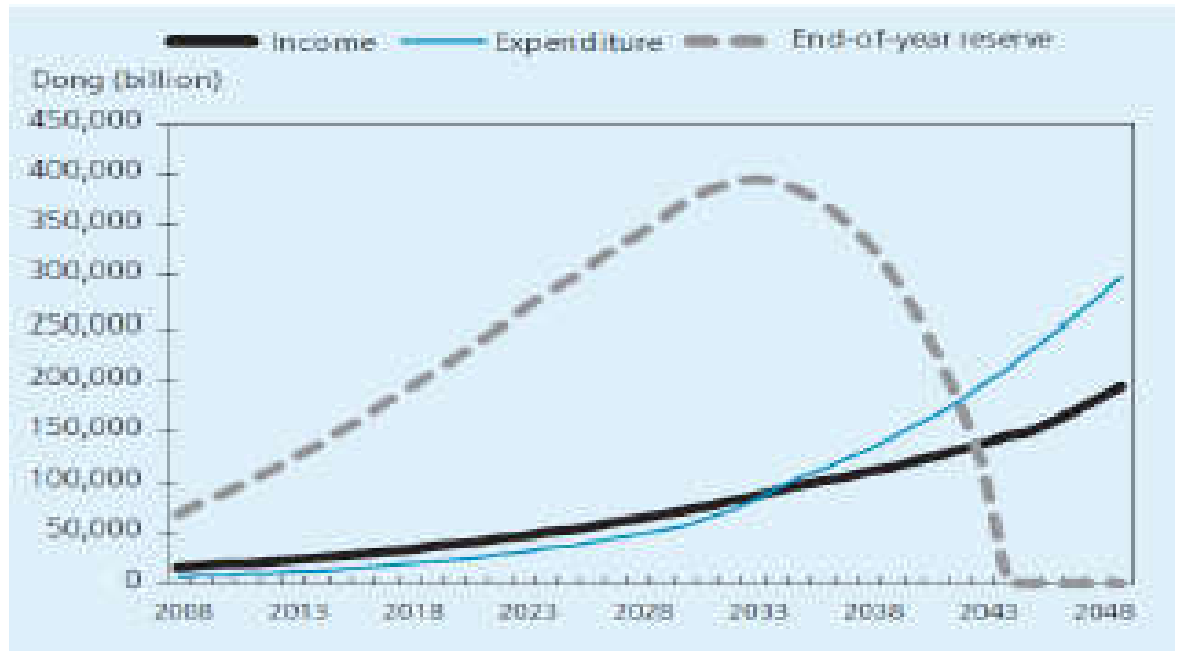

Figure 4. Long-run financial sustainable of Vietnamese pension schemes.

Source: Giang (2014) [12] 
The Vietnamese PAYG DB scheme where current workforce's contribution covers the exact pension payments can be presented by the following equation:

$$
\omega \mathbf{W L}=\mathbf{P R} \text { (1) }
$$

where:

$\omega$ : contribution rate

$\mathrm{W}$ : average nominal wage

L: number of current workers

$\mathrm{P}$ : average nominal pension

$\mathrm{R}$ : number of current retirees

The current demographic shift in Vietnam posits that the number of workers is shrinking and the number of retirees is growing which means a smaller workforce has to support a larger retired generation. We will now consider equation (1) with their exogenous variables before. The PAYG DB may remain its equilibrium in various ways. Firstly, the Government can increase the contribution rate $\omega$ which means the adverse effect of demographic changes will entirely stand on the shoulders of the current workers. A significantly increasing contribution rate may discourage the incentive to work. Secondly, the balance can be remained by reducing the average pension $P$, it is however costly as it will not only break the promise previously made to the pensioners but also aggravate pensioners poverty. The third option would be the combination of the first two options. Two alternative solutions may arise if (i) output increases (reflected by an increase in average wage) and/or (ii) the pension schemes are reformed in order to assure the balance of equation (1): in these cases, the pensioners get what they were promised without further burdening on current workers. Nevertheless, boosting economic growth and/or undertaking an adequate reform for pension schemes are never easy tasks for which we may never find a panacea. Thus, the central question which we should focus on is how to empower the people to adequately plan their retirement, even without an effective pension schemes?

\section{Financial literacy}

At the Conference on Financial Education co-organised by OECD/World Bank/Reserve Bank of India in March 2013, it was acknowledged that empowering financial consumers has become a necessity in an increasingly risky, broad and complex financial landscape. Given the asymmetry of information and limits of financial consumer protection, people must be able to make well-informed financial decision. Researchers and policymakers now recognize the vital role of financial literacy or financial capability in achieving financial wellbeing, combating poverty and sustaining economic growth.

Yet there is a widespread agreement in recent international research that the levels of financial literacy is unacceptably low in both developed and developing countries [13, 14] but little data exists as only a small number of countries have undertaken nationally representative surveys on this topic.

Miller, Godfrey, Levesque, \& Stark (2009) argue that evaluating financial literacy in developing countries is challenging due to the inherent complexity of measuring its effectiveness and the lack of baseline survey data [14].

By mapping the current status of financial literacy in Asia, Yoshino, Morgan, and Wignaraja (2015) reveal that not only the surveys remain limited in terms of economies and targeted groups surveyed but also methodologies and results are not consistent [15].

SBV (2015) reports that the overall financial literacy of the population in Vietnam is very low, especially vulnerable groups, and to date, there is no national financial education program and policy. Low financial literacy in Vietnam leads to wrong financial decisions and cause hardship for people and enterprises to get access to financial services and thus to be more likely to rely on informal lenders [16]. 
Conducted in 16 countries across Asia Pacific since 2011, the MasterCard's Financial Literacy Index serves as a tool to assess and track the progress of financial wellbeing within these countries and benchmark themselves against their regional peers [17]. Its questionnaire covers three major components: Basic Money Management (50\% weight) which examines respondents' skills with regards to budgeting, savings, and responsibility of credit usage; Financial Planning $(30 \%$ weight $)$ which assesses knowledge about financial products, services, and concepts, and ability to plan for long-term financial needs such as retirement and unexpected events; and Investment (20\% weight) which determines respondents' basic understanding of the various risks associated with investment, different investment products and skills required.

The marginal decline of the Financial literacy index in Asia Pacific from 67 in 2012 to 65 in 2014 has allowed Vietnam to catch up the regional average in 2014 with a slightly improvement in terms of ranking (from 12/16 in 2013 to $11 / 16$ in 2014).

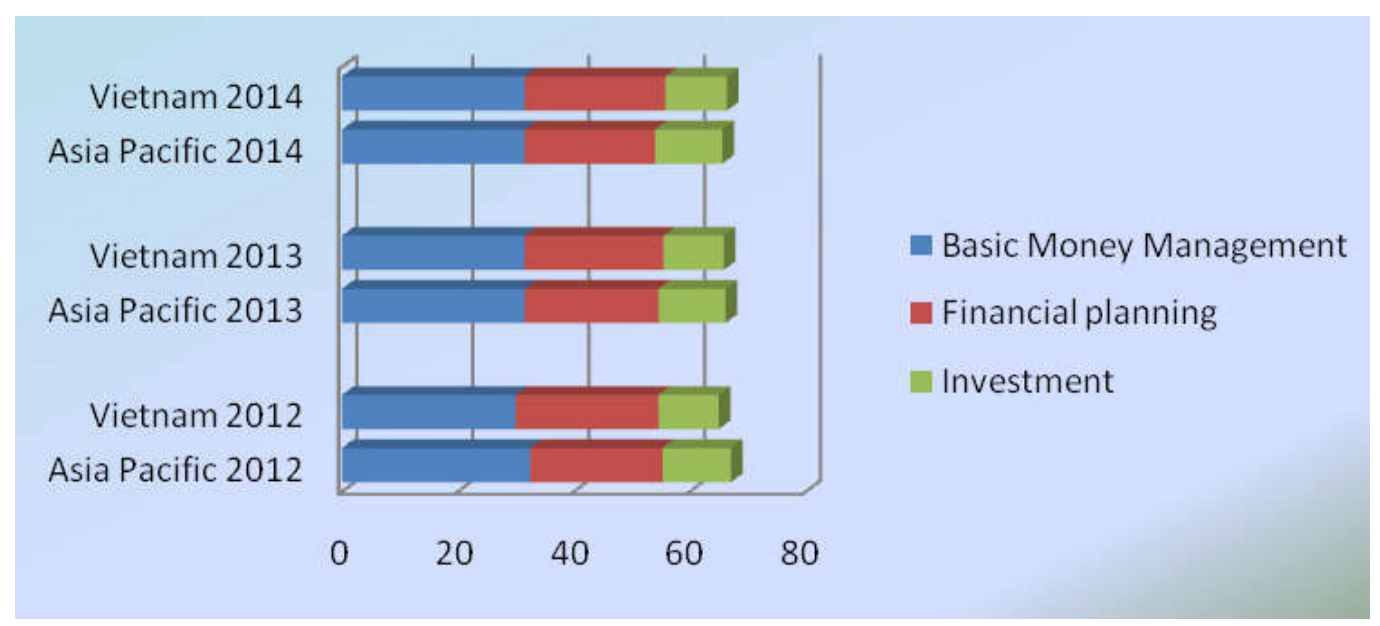

Figure 5. Financial literacy Index of Vietnam: component analysis.

Source: Mastercard Financial literacy index reports in 2013, 2014, 2015

The Vietnamese overall index and its component scores for Basic Money Management and for investment remain lower than the region's average. However, it is interesting to note that its score for financial planning is relatively high and occupies a high rank in the region (\#2 in 2014). There are some reasons that may explain Vietnamese consumers' prudence and active role in financial planning. Firstly, saving is an inherent habit for the agrarian population who must prepare for bad harvests, acts of God and the old age without formal retirement supports. Secondly, most of the population has experienced uncertainties associated to the war, the Subsidy phase as well as the economic transformation which prompted them to financially plan ahead. Thirdly, they are not confident that the pensions will be sufficient to cover their retirement expenses due to (i) the persistent low coverage of pension funds scheme, particularly for the informal sector workers via the voluntary scheme [9] and to (ii) the modest amount of pension benefits. Indeed, despite a relatively high replacement rate in Vietnam, covering all living expenses by pension remains problematic because contribution rate and replacement rate are based on minimum salary which may be, in most of cases, significantly lower than effective 
revenue. This lack of confidence induced Vietnamese people to be active and prudent savers (save regularly and save for emergency).

A demographic analysis by age, working status and income shows that Vietnamese who are mature (more than 30 years old), working and have income higher than average exhibit better financial skills than the other groups, which is consistent with the Asia Pacific's result. The better performance of these population groups can be explained by (i) a greater exposure and experiences associated to financial products and investments opportunities (corporate insurance, mandatory pension funds, investment in stocks, financial risks) which comes from their working life and/or their regular stream of income; (ii) a better ability to regularly contribute toward a retirement plan and to afford life, insurance and investment, and (iii) a larger likelihood to obtain higher education and financial education.

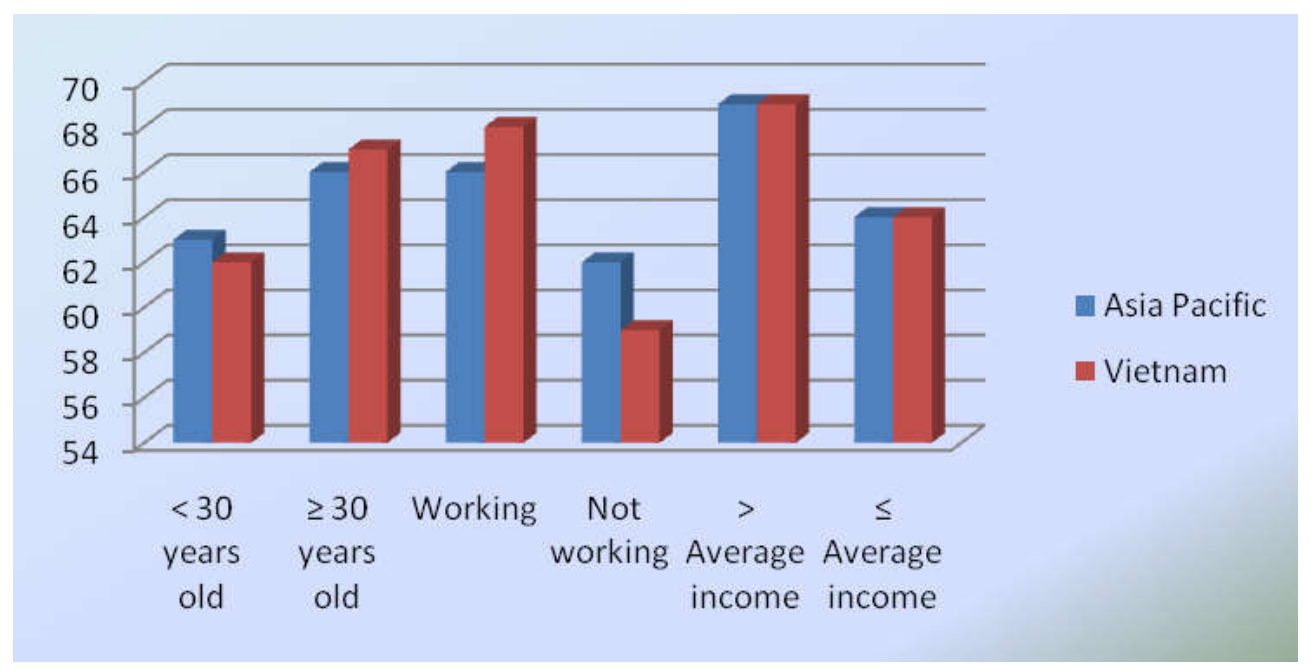

Figure 6. Financial literacy index: demographic analysis (age, work status and household income.

Source: Mastercard Financial literacy index reports in 2013, 2014, 2015

\section{Gender gap}

The systematic and persistent gender gap with men's better performance are generally confirmed by previous research conducted in developed countries such as in the United States, Canada, Germany, Switzerland [18] as well as in Australia, Japan, South Korea (Mastercard, 2015) [17]. This sex difference in financial literacy may be explained by several reasons. Firstly, women have more difficulties than men in catching up with the development of increasingly more sophisticated and complex financial instruments and systems in developed markets. Secondly, women in these countries who are working, married and/or with children, must generally reduce their time for budgeting and financial planning, which may have negative impact on their financial literacy scores.

Contrary to this popular finding, the Mastercard Financial literacy reports point out that, women show slightly better scores than men in Asia Pacific emerging markets with Vietnam leading the region [17]. Vietnamese women scored 8\% better than men's in 2014 . This different pattern in gender gap between developed and developing economies can be quite informative and deserve further discussion and research. The breakdown of Vietnamese women's scores is consistent with the general index of Vietnamese financial literacy where financial planning gets the highest score and 
exhibits a large gap with the other components. Women's good financial performance in emerging markets in general and in Vietnam in particular could be due to several factors. First of all, the financial systems and instruments such as credit facilities, online banking and payments, purchases of bonds, shares and stocks in emerging economies are much less developed. Under these conditions, women and men are more likely to be equally aware and informed about financial issues. In addition, financial planning constitutes a great advantage of women in developing countries. In fact, the low household income and low protection in terms of social security in these countries prompt women, usually regarded as the household's "Chief financial officer", to carefully save and track expenditure on a daily basis in order to plan for big item purchases such as education, health.

\section{Role of financial literacy in retirement planning}

Behrman, Mitchell, Soo, and Bravo (2012) indicate a strongly positive correlation between financial literacy, schooling attainment and wealth [19]. Yoshino, Morgan and Wignaraja (2015) also confirm that financial literacy is positively correlated with economic development and financial development. It is noteworthy that financial literacy may contribute to economic development via a number of macroeconomic and microeconomic channels [15].

Romer (2008) proposes an equilibrium model of endogenous growth in which long-run growth is primarily driven by the accumulation of knowledge by forward-looking, profitmaximizing agents [20]. Production as a function of the stock of knowledge and other inputs exhibits increasing returns; more precisely, human capital constitutes a fundamental source of economic productivity. In contrast to models in which capital has diminishing marginal productivity, the key feature in this endogenous growth theory is the assumption of increasing rather than decreasing marginal productivity of the intangible capital (knowledge). Financial literacy should be now regarded as a component of the human capital which is "the stock of skills and knowledge embodied in the ability to perform labor so as to produce economic value" (Sheffrin, 2003 as cited in Kwon and Dae-bong (2009)) [21]. As stressed by D. E. Bloom, Canning, and Fink (2010), a greater human capital will not only directly stimulate economic growth, but also relieve the tax burden needed to ensure financial sustainability for growing old generations by increasing average income levels [4].

Lusardi and Mitchell (2011) estimate that those who have a planning retirement are 3 times wealthier, at their retirement ages, than those who did not have such plan [13]. Porteba (1996) argues that, amongst other things, there are two important reasons why individuals may fail to save for retirement: (i) some households do not recognise the value of planning for their old age and (ii) the others may have incorrect expectation of their retirement income, life expectancy and post-retirement consumption needs [22].

From microeconomic modelling point of view, forward-looking individuals maximize their expected lifetime utility by using economic information to smooth consumption as well as to accumulate and manage retirement assets over their working life. In the simplest formula, a consumer's lifetime expected utility (EU) depends on the expected value of the sum of per-period utilities $U(\mathrm{cj})$ discounted to the present:

$$
E_{U}=\sum_{j=x}^{D} \beta i \cdot x_{U}\left(c_{j}\right)
$$

where

cj: per-period consumption

D: oldest lifetime 
$\mathrm{X}$ : current age of the individual

$\beta$ : discount factor, where: $\beta=\frac{1}{1+p}$ and $\rho$ is the discount rate/time preference rate. A positive $\rho$ : impatience or time preference.

Income (yj) for this individual in the working age is represented as follows:

$$
y_{j}=e_{j}+r a_{j}+s b_{j}, j \in[X, \ldots, R-1]
$$

where

ej : labor earning

raj: return on asset aj

sbj: social security benefits

$\mathrm{R}$ : retirement age

and at retirement age:

$$
y_{j}=\operatorname{pen}_{j}(R)+s b_{j}+r a_{j}, j \in[R, \ldots, D]
$$

where

penj(R): pension

The maximization of the utility function [23] is subject to the lifetime budget constraint determined as follows:

$\mathrm{cj} \leq \mathrm{yj}+\mathrm{aj}, \mathrm{j} \in[\mathrm{S}, \ldots, \mathrm{D}]$

(to simplify, we suppose that the assets are equal to zero and the consumer does leave any debt in the last period of life).

These equations suggest that individual must take into account discount rates, asset returns, earnings, social security benefits expected to formulate and execute optimal consumption and saving plans to ensure their comfortable life. In that connection, financially literate people will be more likely to allocate their financial decisions and thus increase their saving rates and wisely choose where to put their savings in. It will positively impact the economy in many ways:

Firstly, the more people are financially literate, the more they have a long-term perspective with life insurance and retirement planning and thus, save more. An increase in domestic saving would booster investment with a much more sustainable and stable sources than other capital flows, and this in turn will foster economic growth. In fact, assets from pension funds and insurance companies can be an important source of financing for infrastructure investment. Given the critical role of infrastructure development in supporting sustainable growth in Vietnam, promoting such saving will constitute a valuable contribution.

Secondly, a higher sense of risk diversification will prompt households and companies to have smart allocation of their assets on risky investment with high return and safe investment with low return. This would work as market disciplines which increase companies' motivation to improve the productivity of their projects as they must compete to get access to the funding.

Thirdly, a better financial education will enable households and small and medium-sized entrepreneurs to enhance self-protection and reduce risks by minimizing the probability of defaults and avoiding the mis-selling of financial products.

\section{Concluding remarks and discussion}

Our findings from this research provide a dull sketch of financial literacy as well as financial situation of the elderly and their retirement planning. Financial literacy is low in Vietnam and remains a low rank in the Asia Pacific region. However, Vietnamese are relatively strong in financial planning in comparison with other countries in the region. This good performance in financial planning which make Vietnameses active and regular savers can be explained by the characteristics of agrarian population, experience of economic uncertainties and lack of confidence in pension schemes. A demographic analysis by age, working status and income shows that Vietnamese young people, not working with low household income are less financially literate, which is consistent with the Asia Pacific's result.

Financial situation of the elderly in Vietnam is worrisome as nearly two-thirds of the elderly surveyed by VNAS (2011) estimate their 
finances as permanently or sometimes insufficient and just a small proportion of them have savings [11]. The most important source of incomes of the elderly for daily expenses comes from their children support and only $16 \%$ of the elderly consider pension as their main income stream. This renders the elderly's financial security more problematic as the urbanisation with massive flows of immigration is now eroding the traditional family structure and may increase the number of the aged popuplation living without care and financial supports from their family members.

The financial sustainability of the pension schemes of Vietnam is questionable due to its unlikelihood to insulate the system from demographic shocks which is happening to the country. Though there's still not a blueprint for this situation, apparently the optimal choice at the moment is to improve retirement readiness. This is crucial since being able to plan and prepare for their retirement ages constitutes the key to retirement security. In that connection, nationwide financial education programmes are required in the very near future to empower Vietnamese to adequately prepare their retirement. A wise retirement planning needs knowledge and skills for active and regular savings but also for smart investment with risk diversification perception to navigate through safe but with low interest and risky but with high interest investments. Financial literacy is thus critical to retirement security, particularly for the most vulnerable groups.

\section{References}

[1] OECD (2015). Pension Markets in Focus.

[2] Park, D., Lee, S.-H., \& Mason, A. (Eds.). (2012). Aging, Economic Growth, and Old-Age Security in Asia: Edward Elgar.

[3] UNFPA Vietnam. (2011). The ageing population in Vietnam: Current status, prognosis, and possible policy responses Report.

[4] Bloom, D. E., Canning, D., \& Fink, G. (2010). Implications of population ageing for economic growth. Oxford Review of Economic Policy, 26.
[5] Peterson, P. (1999). Gray Dawn: The Global Aging Crisis. Foreign Affairs, January/February.

[6] Park, D. (Ed.) (2012). Pension Systems in East and Southeast Asia Promoting Fairness and Sustainability: Asian Development Bank.

[7] Bloom, D., \& Mc Kinnon, R. (2013). The Design and Implementation of Public Pension Systems in Developing Countries: Issues and Options. IZA Policy Paper, 59.

[8] ILO. (2010). World social security report: providing coverages in times of crisis and beyond. Geneva: International Labor Office.

[9] Giang, T. L. (Ed.) (2010). Social Protection in Vietnam: Current State and Challenges (Vol. ERIA Research Project Report 2009-9,). Jakarta: ERIA.

[10] OECD \& World Bank (2013). Pensions in Asia/Pacific, Ageing Asia must face its pension problems. Retrieved from

[11] Vietnam National Aging Survey 2011 - Key findings technical report.

[12] Giang, T. L. (2014). A brief on Vietnamese pension schemes. Paper presented at the Regional Consultation on Strengthening Income Support for Vulnerable Groups, Incheon, Republic of Korea, 26-27 March, 2014.

[13] Lusardi, A., \& Mitchell, O. S. (2011). Financial Literacy around the World: An Overview. NBER Working Paper, No. 17107.

[14] Miller, M., Godfrey, N., Levesque, B., \& Stark, E. (2009). The Case for Financial Literacy in Developing Countries: Promoting Access to Finance by Empowering Consumers. Retrieved from The International Bank for Reconstruction and Development/The World Bank:

[15] Yoshino, N., Morgan, P. J., \& Wignaraja, G. (2015). Financial Education in Asia: Assessment and Recommendations. ADBI Working Paper Series, 354.

[16] SBV (2015). Evaluation of Financial literacy in Vietnam and National Financial education program. Paper presented at the ADBI.

[17] MasterCard Financial Literacy Index Reports 2013, 2014, 2015.

[18] Brown, M., \& Graf, R. (2013). Financial Literacy and Retirement Planning in Switzerland. Numeracy Advancing Education in Quantitative Literacy, 6(2).

[19] Behrman, J. R., Mitchell, O. S., Soo, C. K., \& Bravo, D. (2012). How Financial Literacy Affects Household Wealth Accumulation. American Economic Review, 102(3). 
[20] Romer, P. M. (2008). Increasing Returns and LongRun Growth. The Journal of Political Economy, 94.

[21] Kwon, \& Dae-bong. (2009). Human capital and its measurement. Paper presented at the The 3rd OECD World Forum on "Statistics, Knowledge and Policy" Charting Progress, Building Visions, Improving Life, Busan Korea.
[22] Porteba, J. M. (1996). Personal saving behavior and retirement income modelling: A research assessment. . Washington: National Academy Press.

[23] Kibet, L. K., Mutai, B. K., Ouma1, D. E., Ouma, S. A., \& Owuor, G. (2009). Determinants of household saving: Case study of smallholder farmers, entrepreneurs and teachers in rural areas of Kenya. Journal of Development and Agricultural Economics, 17. 